\title{
SOME SOCIO-ECONOMIC AND CULTURAL FACTORS IN WEST AFRICAN PAEDIATRICS
}

\author{
BY \\ BRUNO GANS \\ From the Paediatric Department, Lewisham Hospital, London
}

(RECEIVD FOR PUBLICATION SEPTEMBER 7, 1962)

'The Progress of Medicine in the Developing Countries must depend largely on its Social Content.' Cicely Williams

The type and frequency of paediatric disease in many parts of Africa has been described by several workers, and fairly accurate information is now available (Luder, 1957; MacGregor, 1958; Carter, 1961 ; Musoke, 1961; Gans, 1961 ; Senecal, Aubry and Falade, 1962).

As knowledge of diseases affecting children in the tropics becomes more complete, it is essential for paediatricians to try to understand more about the patients' cultural background. Clearly, there is an important connexion between the illness observed in the children and their parents' financial status, their educational attainments, the pattern of family life and society's attitude to disease, its causation and its cure. It is significant that Professor D. B. Jelliffe chose as his subject for the 1962 Windermere Lecture this very interplay between 'scientific' paediatrics and the cultural pattern in which it takes place in many of the New Nations.

Few paediatricians are fortunate enough to have been trained in sociology, economics and anthropology, in addition to their medical speciality. Information on non-medical subjects must be gathered by the investigator who may misunderstand or understand only incompletely what he is told. He usually has to rely on statements and interpretations made by intelligent and interested indigenous colleagues and nurses. The interpretation of information is sometimes made more difficult by the, often subconscious, rejection of traditional beliefs and practices by the informant.

This paper attempts in a very elementary way to apply some basic socio-economic and cultural data to the evaluation of day-to-day paediatrics as seen in a large tropical town in West Africa. The data were collected during a period of 30 months' secondment, between 1959 and 1961, to the General Hospital, Lagos, Nigeria. Information was obtained from about 1,000 mothers and their children seen in the out-patients' department of that hospital. The author is only too well aware of his inadequate qualifications for this type of inquiry and must ask the indulgence of those of his colleagues who have a more adequate grasp of sociological, anthropological and economic techniques.

The children's age, sex, illnesses and weights; their fathers' and mothers' income and employment; the mothers' school attendance, the number and fate of their children and the number of wives in the family, were recorded. About half the mothers were questioned by the author through an interpreter. The other half were interviewed, almost always without the need for an interpreter, by a Nigerian colleague working in the same clinic room at the same time. It has been suggested that the mothers' answers to questions about the number of wives in the family and also the number of their children who had died might, for one reason or another, not be reliable. This is possible, but the fact that one of the doctors was a Nigerian probably lessened the risk of inaccuracy, or at any rate spread the unreliable data evenly throughout the sample.

Inevitably, the analysis of results had to be statistical. Several possible sources of error will become obvious at once, even to the non-expert statistician. The reliability of information about the mothers' income may be doubted. Perhaps it is worth mentioning that in Nigeria the great majority of women are engaged in trading on a greater or lesser scale, the goods sold ranging from a single cigarette or two lumps of sugar to wholesale commerce in bales of imported cloth. According to Marris (1961) $90 \%$ of the Lagos wives work, mainly by trading. The Lagos mother either does not want to, or cannot afford to, become wholly dependent on her husband. She uses her profits for her children, herself or her relatives, and often considers her trade more important than her 
housework. She is not necessarily obliged to contribute her trading profits to the husband's household expenditure. Husband and wife rarely know what each other earns, and should the husband be very poor, out of work, or ill, he may rely on the earnings of his wife or wives.

In this investigation, each mother was asked to divulge the weekly profit she made from her trade. Clearly, her statement might be at variance with the facts. However, an error of this type would presumably always be uni-directional. In the event, it proved possible to divide the mothers into six fairly clear-cut income groups. The author is indebted to Mr. P. Marris for suggesting this simple method of economic classification, a classification that yielded such fascinating information in his study of rehousing in Lagos (Marris, 1961).

Another possible source of error is perhaps inevitable in all attempts to allocate women to socio-economic groups: all mothers who did not earn an income were classified as "housewife". Probably this group is too heterogeneous.

On the positive side it may be worth stressing that the children's ages are correct. After the introduction of free primary education for children born in the Federal Capital it was obligatory for parents to register their children's birth within one month of delivery. Only children whose age was accurately known were included in this study. The size of the sample ( 984 children, none of them older than 5 years) was probably adequate. They were seen in the only out-patients paediatric clinic in existence in Lagos at that time. Access to the clinic was free and the very great majority of diseases seen were acute. The conclusions based on the sample very probably allow the assumption that the children, and their mothers, were representative of the population of Lagos and its immediate surroundings. It must be remembered that these data were collected from mothers who attended with their children between 1959 and 1961. Lagos is a rapidly growing and rapidly changing town, and facts that held during the period of the survey may well not be applicable in the future.

The mothers economic groups were made up as follows: Group I included mothers who had been educated to a point that allowed them to practise a profession, or to be employed in a responsible managerial or secretarial capacity. Their annual income was invariably several hundred pounds. Group II were the housewives who did not have to trade or to earn a living. Group III were women engaged in wholesale or retail trade in cloth, with a weekly profit of between two and twenty pounds. Although well off financially, quite a number of them had received no formal schooling. Group IV earned their living by sewing or knitting and admitted to a weekly profit of up to thirty shillings. Group V were hairdressers, saleswomen of fresh fish, plates, cigarettes or 'provisions', i.e. those with a diverse stock. They claimed a profit of up to twenty-five shillings per week. The mothers of Group VI sold pepper, gari, wood, rice, vegetables, ogi, fruit, face powder, leaves, palm oil, yams, beans, ewa, cola nuts, salt, herbs, bread, bottles, groundnuts in small tins, or tooth sticks. Few showed more than ten shillings profit a week.

When comparing these groups, the first, second and third were contrasted with the fifth and sixth as. clearly, there was a marked financial and educational difference between Groups I to III and V to VI. As mentioned above, the interpolation of housewives' between socio-economic Groups I and III was arbitrary, but appeared to be justified because mothers of this group were not obliged to contribute to the family income and were presumably fairly well-to-do.

Naturally, this classification was used with some discretion. Saleswomen employed in stores, though

TABLE

WEIGHT OF 539 BOYS AND 445 GIRLS. FROM BIRTH TO 60 MONTHS

\begin{tabular}{|c|c|c|c|c|c|c|}
\hline \multirow{2}{*}{$\begin{array}{c}\text { Age } \\
\text { (mths) }\end{array}$} & \multicolumn{3}{|c|}{ Males } & \multicolumn{3}{|c|}{ Females } \\
\hline & No. & $\begin{array}{l}\text { Mean } \\
\text { (lb.) }\end{array}$ & S.D. & No. & $\begin{array}{l}\text { Mean } \\
\text { (lb.) }\end{array}$ & S.D. \\
\hline $\begin{array}{l}0 \\
1 \\
2 \\
3 \\
4 \\
5 \\
6 \\
7 \\
8 \\
9 \\
10 \\
11 \\
12 \\
13 \\
14 \\
15 \\
16 \\
17 \\
18 \\
19 \\
20 \\
21 \\
22 \\
22 \\
23 \\
24 \\
25-27 \\
28-30 \\
31-33 \\
34-36 \\
37-39 \\
40-42 \\
43-45 \\
46-48 \\
49-51 \\
52-54 \\
55-57 \\
58-60\end{array}$ & $\begin{array}{r}37 \\
20 \\
20 \\
8 \\
10 \\
11 \\
20 \\
15 \\
15 \\
23 \\
17 \\
17 \\
24 \\
15 \\
16 \\
18 \\
9 \\
8 \\
25 \\
9 \\
7 \\
10 \\
6 \\
6 \\
37 \\
14 \\
21 \\
7 \\
23 \\
4 \\
9 \\
7 \\
23 \\
1 \\
7 \\
6 \\
14\end{array}$ & $\begin{array}{r}6 \cdot 6 \\
8 \cdot 0 \\
9 \cdot 2 \\
11 \cdot 4 \\
11 \cdot 2 \\
11 \cdot 0 \\
13 \cdot 3 \\
13 \cdot 2 \\
16 \cdot 2 \\
14 \cdot 6 \\
16 \cdot 7 \\
15 \cdot 2 \\
16 \cdot 3 \\
15 \cdot 5 \\
18 \cdot 8 \\
17 \cdot 7 \\
18 \cdot 1 \\
16 \cdot 1 \\
17 \cdot 0 \\
19 \cdot 7 \\
20 \cdot 1 \\
17 \cdot 8 \\
20 \cdot 8 \\
22 \cdot 6 \\
18 \cdot 4 \\
22 \cdot 1 \\
21 \cdot 3 \\
23 \cdot 9 \\
24 \cdot 2 \\
27 \cdot 1 \\
28 \cdot 1 \\
24 \cdot 7 \\
30 \cdot 2 \\
42 \cdot 0 \\
31 \cdot 4 \\
30 \cdot 9 \\
30 \cdot 8\end{array}$ & $\begin{array}{l}1 \cdot 59 \\
2 \cdot 12 \\
3 \cdot 95 \\
2 \cdot 31 \\
2 \cdot 29 \\
4 \cdot 72 \\
4 \cdot 23 \\
4 \cdot 94 \\
5 \cdot 11 \\
2 \cdot 95 \\
3 \cdot 23 \\
4 \cdot 29 \\
3 \cdot 20 \\
3 \cdot 61 \\
4 \cdot 51 \\
4 \cdot 10 \\
7 \cdot 25 \\
2 \cdot 97 \\
3 \cdot 55 \\
5 \cdot 05 \\
8 \cdot 84 \\
2 \cdot 46 \\
5 \cdot 07 \\
3 \cdot 72 \\
4 \cdot 04\end{array}$ & $\begin{array}{r}34 \\
13 \\
11 \\
14 \\
10 \\
8 \\
16 \\
11 \\
13 \\
10 \\
15 \\
17 \\
24 \\
5 \\
5 \\
12 \\
13 \\
9 \\
26 \\
7 \\
10 \\
7 \\
2 \\
5 \\
42 \\
11 \\
21 \\
4 \\
20 \\
4 \\
8 \\
5 \\
13 \\
1 \\
5 \\
13 \\
13\end{array}$ & $\begin{array}{l}7 \cdot 5 \\
6 \cdot 8 \\
8 \cdot 0 \\
10 \cdot 1 \\
12 \cdot 4 \\
12 \cdot 6 \\
12 \cdot 1 \\
11 \cdot 4 \\
13 \cdot 6 \\
13 \cdot 1 \\
14 \cdot 4 \\
14 \cdot 3 \\
14 \cdot 5 \\
15 \cdot 6 \\
13 \cdot 6 \\
15 \cdot 2 \\
17 \cdot 3 \\
14 \cdot 9 \\
17 \cdot 3 \\
14 \cdot 8 \\
18 \cdot 0 \\
16 \cdot 7 \\
12 \cdot 8 \\
20 \cdot 9 \\
18 \cdot 5 \\
20 \cdot 5 \\
20 \cdot 9 \\
28 \cdot 8 \\
24 \cdot 5 \\
29 \cdot 0 \\
22 \cdot 2 \\
24 \cdot 9 \\
22 \cdot 7 \\
32 \cdot 0 \\
30 \cdot 1 \\
31 \cdot 5 \\
29 \cdot 2\end{array}$ & $\begin{array}{l}1 \cdot 61 \\
1 \cdot 51 \\
3 \cdot 27 \\
2 \cdot 81 \\
3 \cdot 60 \\
4 \cdot 81 \\
4 \cdot 93 \\
4 \cdot 89 \\
4 \cdot 01 \\
3 \cdot 77 \\
3 \cdot 88 \\
3 \cdot 67 \\
3 \cdot 17\end{array}$ \\
\hline
\end{tabular}



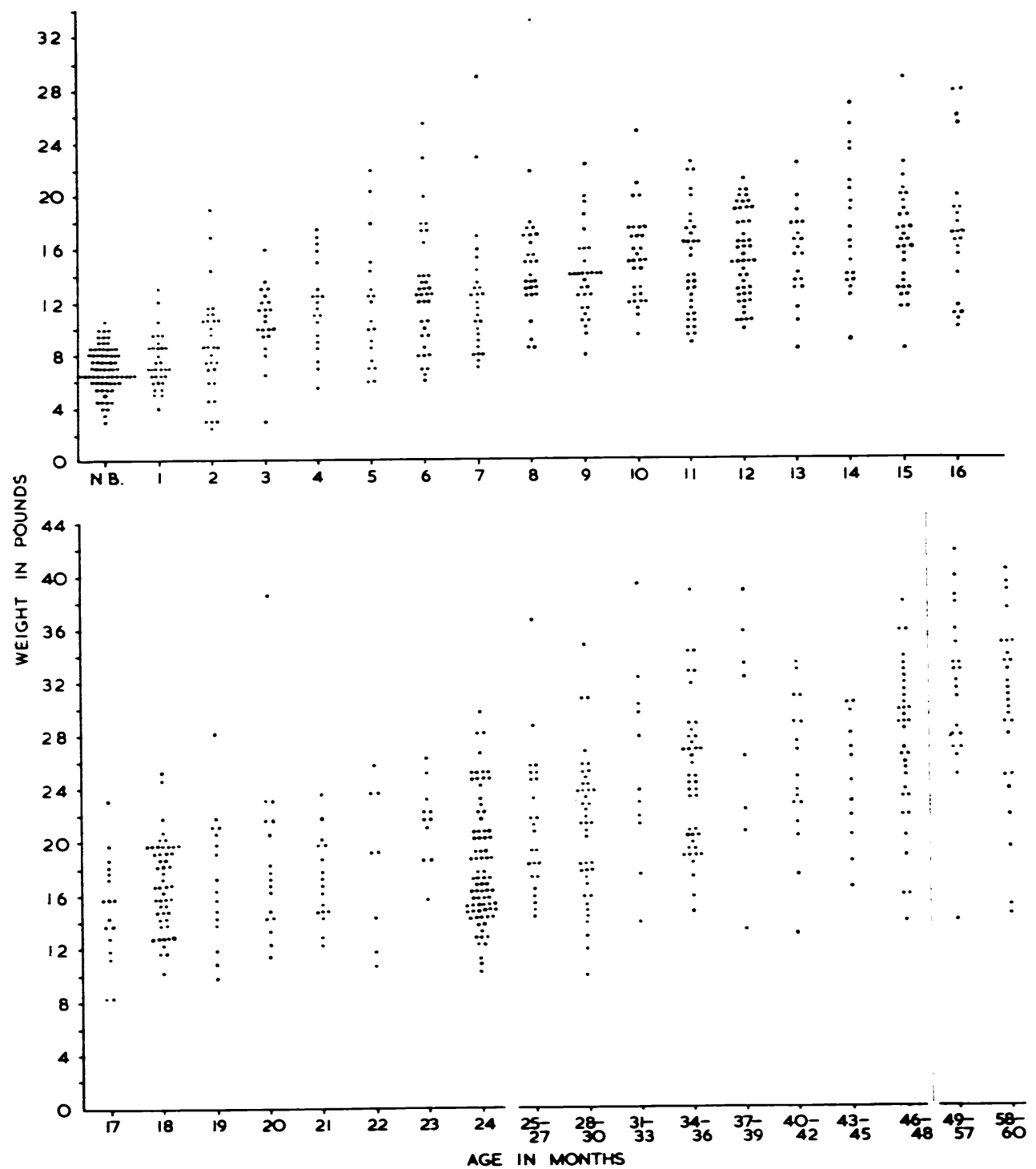

Fig. 1.-Weight of 984 children aged 0-60 months. Lagos. 1959-1961.

literate, had to be placed in Group IV. After a while, the mother $s$ bearing, her style of dress and ornament, and the fact that her child appeared well cared for or otherwise, were taken into consideration when allocating the mother to one or other of the six groups. Since no really reliable information is available on the economic grouping of Lagos mothers, other than those given by Marris (1961), one can only assume that the numbers in each group were proportionate to the numbers of each group in Lagos as a whole at that time. Comparison with
Marris's figures suggests that this assumption was justified.

For the fathers' economic grouping the classification of the Lagos Population Census (1953) was adopted. Administrative, managerial and professional occupations were Group I; clerical and salesmen, Group II; tradesmen, Group III; agricultural workers, Group IV; craftsmen and mechanics, Group V; and labourers and unemployed, Group VI. The author allocated medicine men and herbalists to Group I, fire brigade employees, soldiers and 


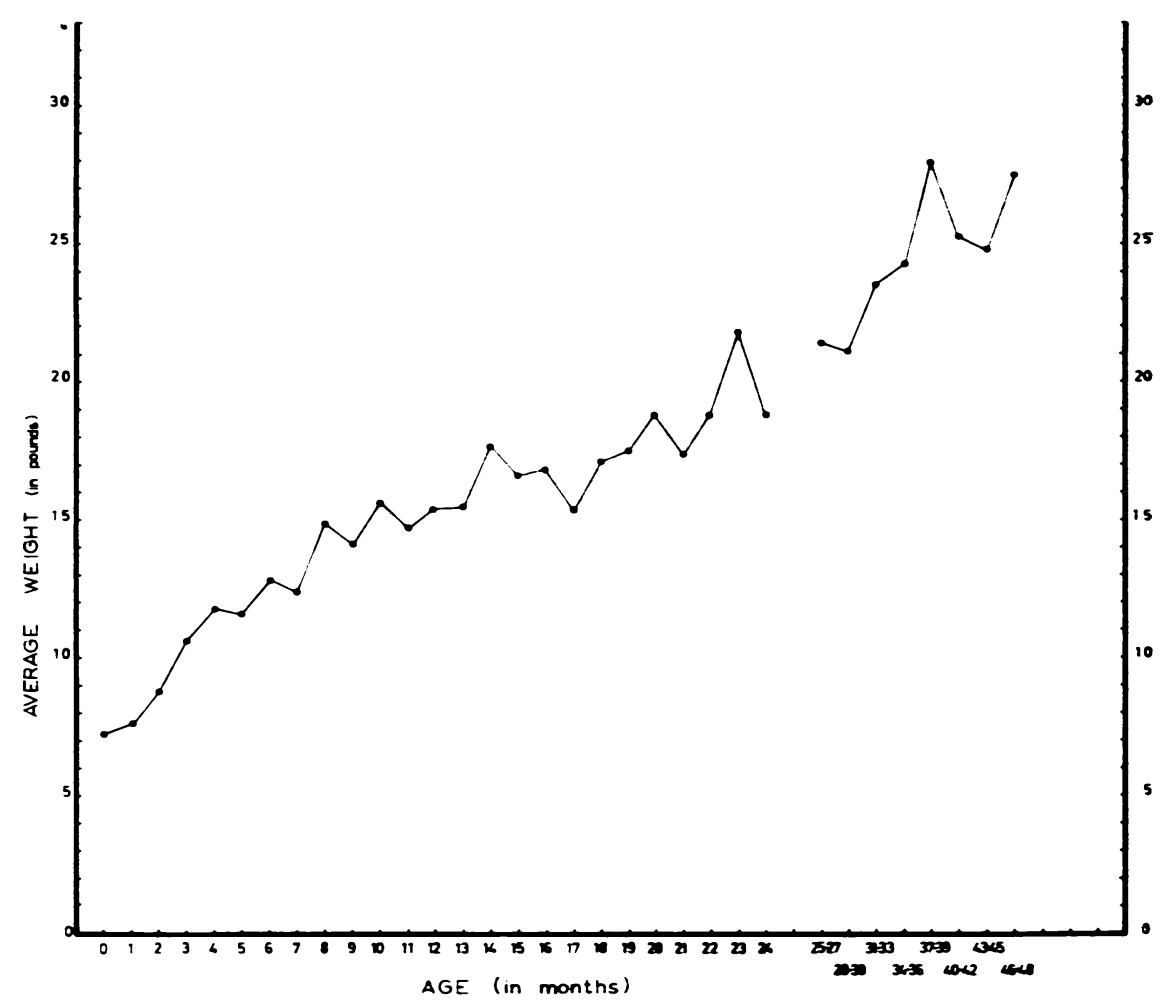

FIG. 2.-A verage weights of 980 children attending O.P.D., General Hospital, Lagos, 1960-1961, age 0-48 months.

police to Group II, and tailors, barbers, gardeners and cook-stewards to Group V. Again there can be no doubt that both the official and the author's additional classification leave much to be desired, but the samples appear to accord well with the distribution of socio-economic groups in Lagos as reported in the Population Census (1953).

Dealing then, first, with the data relating to the children attending the clinic, their weight is obviously of considerable importance. Table 1 shows the weight, by age and sex, of 984 children from birth to the age of 60 months. The standard deviations show that there is a large variation around the means. This scatter is shown graphically in Fig. 1. The small numbers in some of the weight groups preclude the use of the usual percentile comparisons, and even a division by weight into males and females proved impossible, owing to the marked weight oscillations.

The important point that emerges is that in a rapidly growing tropical town extremes of poverty, and therefore of growth disturbance, are the rule. Fig. 2 gives the average weight for each age-group. The limitations of such a curve, in view of the tremendous overlap in each group, must be borne in mind. Comparison of this average weight chart with weights of children in other series is, perhaps. of only limited value, but certain interesting points emerge. Fig. 3 compares the average weight of the children in the present series with that of healthy children attending a Lagos Town Council Infant Welfare Clinic (Watt, 1959); healthy boys at Mulago Hospital, Uganda (Dean and Jelliffe, 1960); and the 50th percentile weight of healthy United States boys (Nelson, 1959). It will be seen that the average birth weight is the same in all four series. The healthy Uganda boy begins to drop below the weight of his American coeval in the middle of his second year. The healthy Lagos Infant Welfare Clinic baby begins to lag behind during the second six months of life, though these infants were quite highly selected in as much as their mothers had shown an enlightened attitude by regularly taking them to one of the Infant Welfare Clinics. All children in the present Lagos General Hospital series were grossly underweight once they had passed the neonatal period.

The objection that these children were seen and their weight recorded because they were ill is, of 


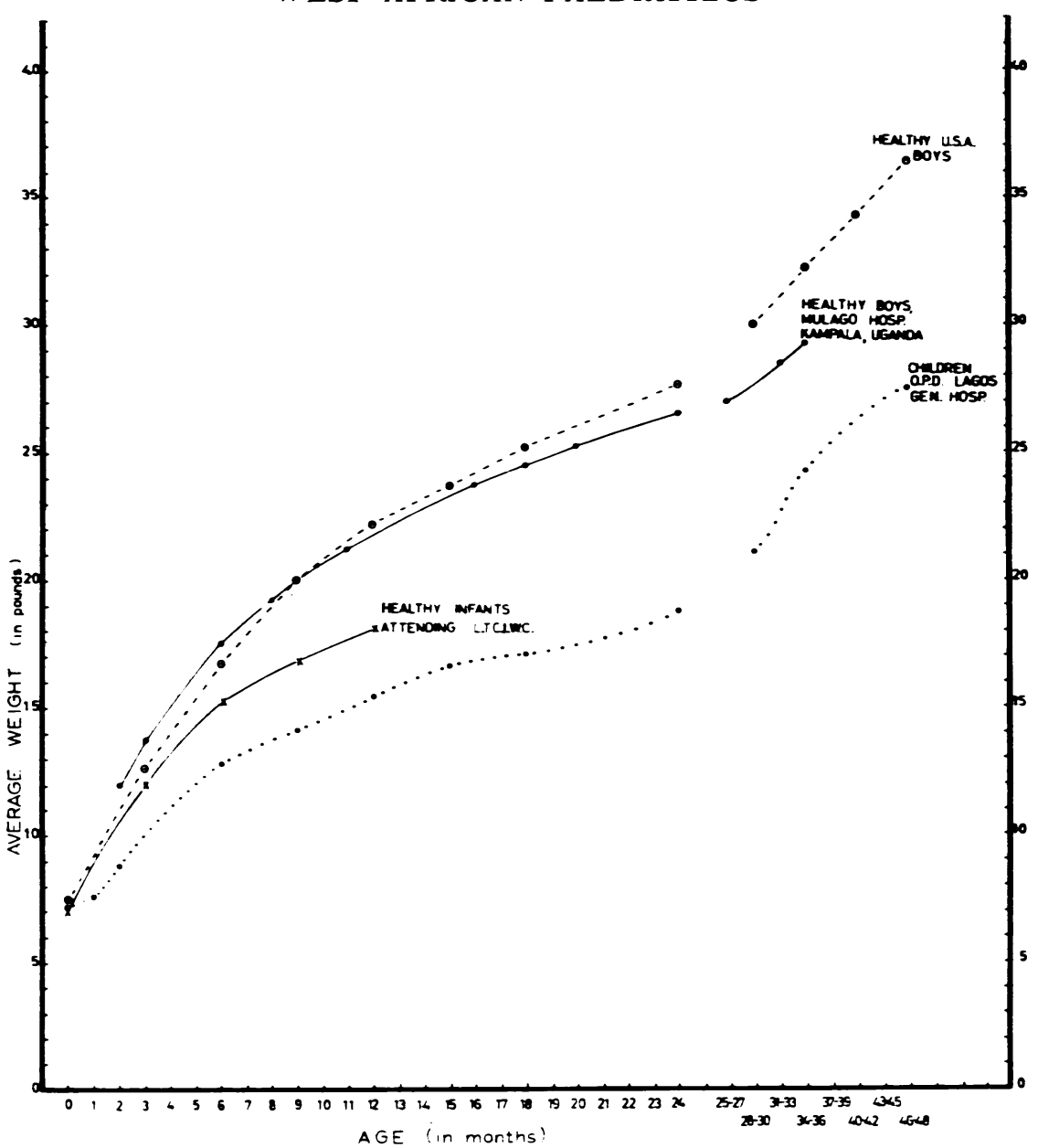

FIG. 3.-Average weights of Lagos General Hospital out-patient children compared with: (1) healthy Lagos Town Council Infant Welfare Clinic infants; (2) healthy boys, Mulago Hospital, Uganda; (3) healthy boys, U.S.A.

course, valid and would account for the low weights recorded throughout this series. However, practically all these children suffered from acute illnesses. The illnesses were of every conceivable medical and surgical type and by no means necessarily associated with weight loss. Further, the relation between the children's weights and their parents' socio-economic groups (to be described below) cannot be explained on the grounds of the children's illness.

Fig. 4 shows the effect of the mothers' educational attainment on the children's weight. All mothers who had attended school, even if only for a few years, were grouped together. The illiteracy rate of this sample was $61.5 \%$. It is clear that the average weight of children whose mothers had attended school is considerably higher than that of children whose mothers were illiterate.
By contrast, there was no significant difference (Fig. 5) between the weight of children whose mothers were the only wives and those who belonged to polygamous households. It was found that $38.2 \%$ of all mothers in the sample were one of several wives in the household. Several odd features emerge from this finding. It will be seen below that polygamy has an adverse effect on the incidence of certain disease states in the children. It will also be shown that maternal literacy and a higher socio-economic group are more common in monogamous families. The failure to find a clearcut difference between the weights of children from polygamous, as compared with monogamous, households remains unexplained.

As might be expected, children of mothers belonging to the higher socio-economic groups 

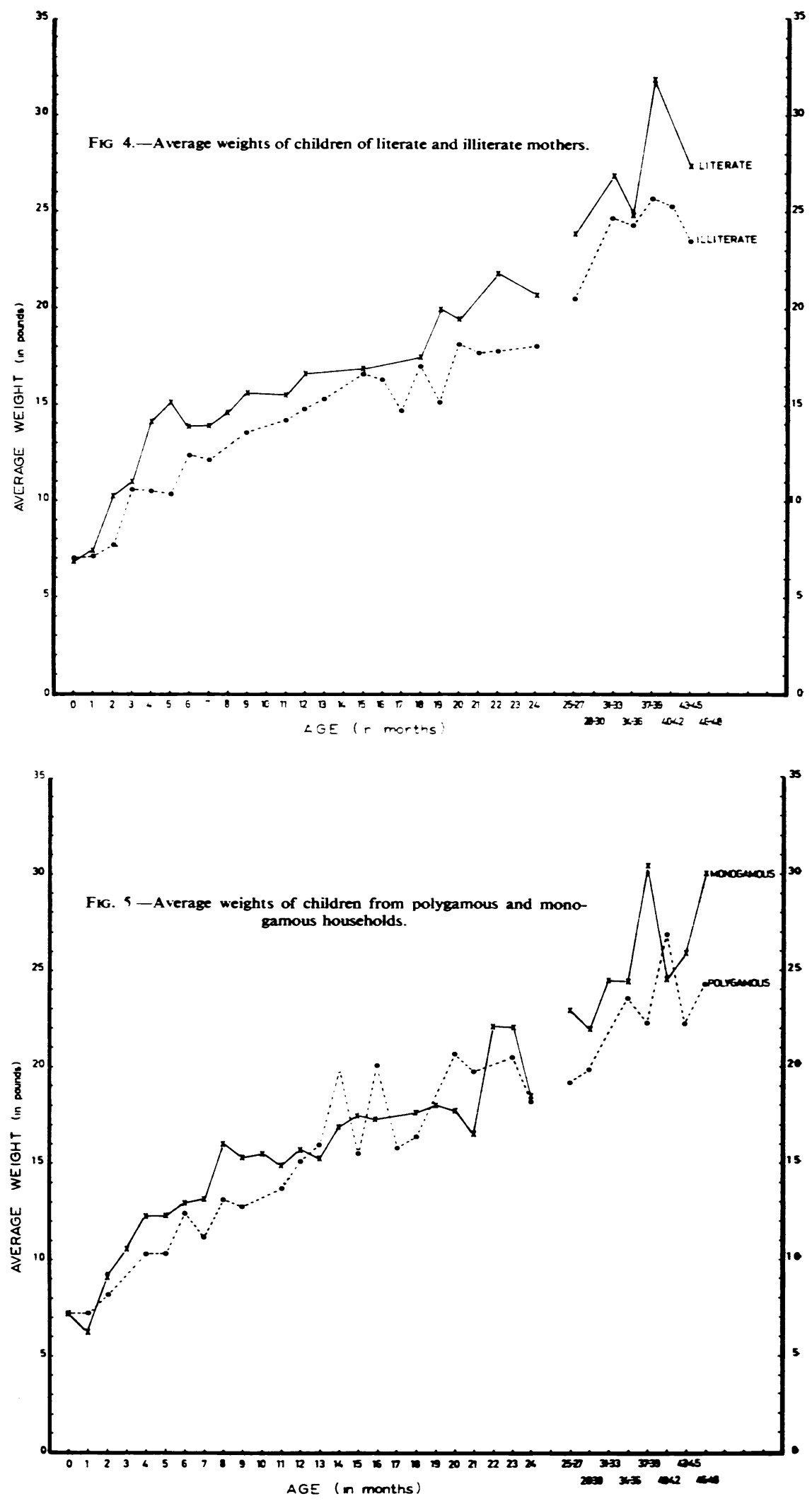


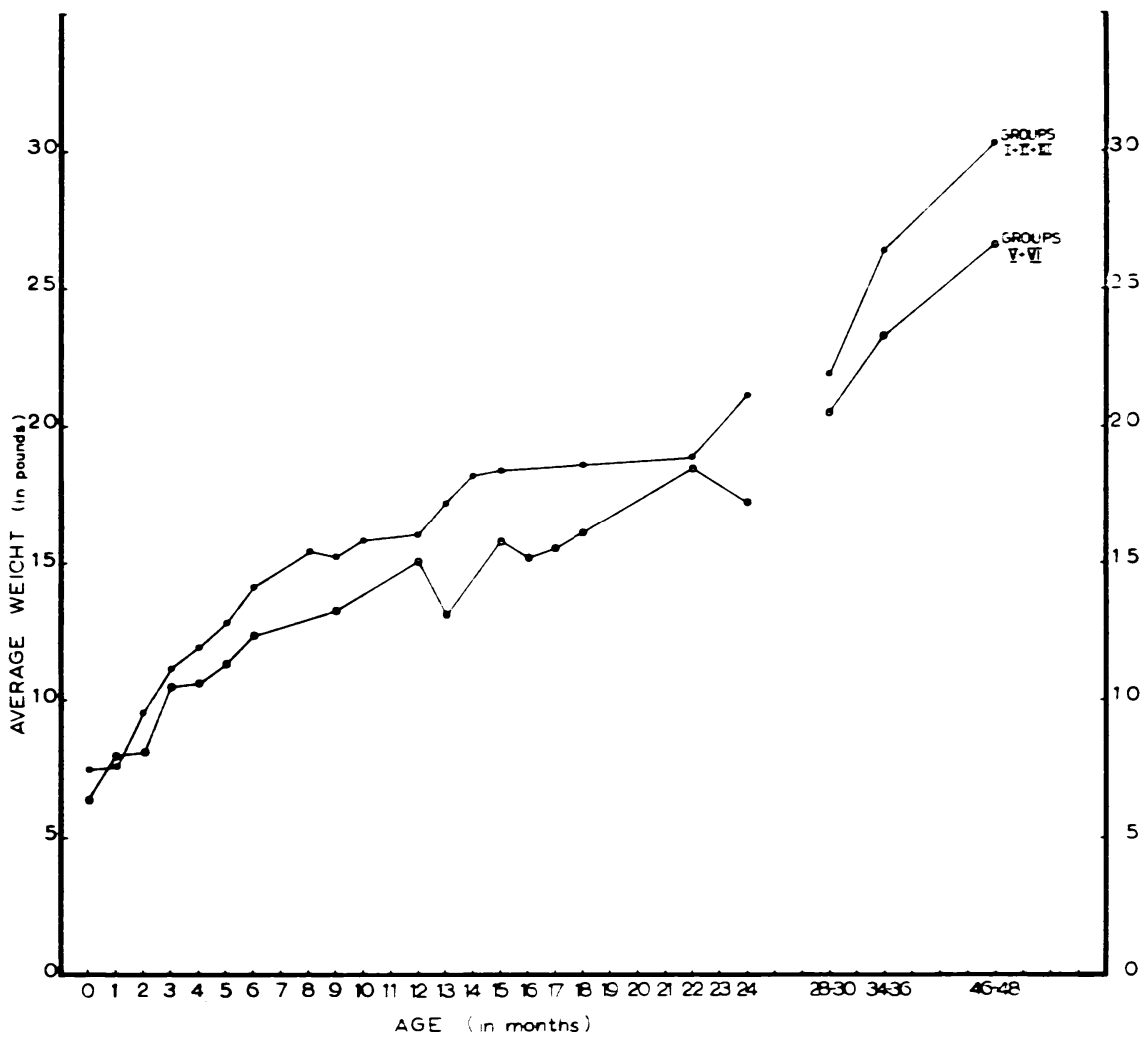

FKG. 6.-Average weights of children of mothers in socio-economic Groups I - II - III and V - VI.

weighed more than those of mothers of the lowest groups (Fig. 6). To bring this out clearly, mothers of Groups I and III, and also those of the somewhat indeterminate Group II, were contrasted with mothers belonging to Groups V and VI. The difference in their children's weight becomes more marked after the age of 6 months. This might mean that the supply of breast milk was adequate in all groups during the first six months, or that the more sophisticated Lagos mothers of Groups I, II and III had turned to bottle feeding and were more successful in doing so than their less well-off sisters of Groups V and VI.

The fathers' socio-economic group did not appear to affect their children's weight (Fig. 7) as much as their mothers' economic group, and such slight advantage as the child of the father of Groups I and II had over the one whose father belonged to Groups V and VI does not show itself until the end of the second year of life. One possible explanation of this finding is that, in spite of polygamy, the Western and Eastern Nigerian society (to whom the great majority of children in this series belonged) is, in fact, matriarchial. As Marris (1961) points out, siblings are united through their mother, rather than their father, and feel their closest tie with their mother. He found that $11 \%$ of husbands did not live with any of their wives, that $50 \%$ of polygamous fathers lived apart from at least one wife, and that $25 \%$ of wives did not live in the father's polygamous household. This state of affairs is bound to have a marked effect on the fate of the children. Marris found that $20 \%$ of young children lived with neither father nor mother (presumably because the mother was expecting another child), that $18 \%$ lived with the mother and not with the father, and that $7 \%$ lived with the father and not with the mother. In only $55 \%$ of Marris's sample did the young child live with both mother and father.

Turning now to the mothers' social state and its effect on the number of their children who survive, it appears that polygamy has a significant, though relatively small, influence on child survival: of 1,858 children born to mothers of monogamous households, $378(20.3 \%)$ died, whereas of 1,281 children born to mothers of polygamous households, 


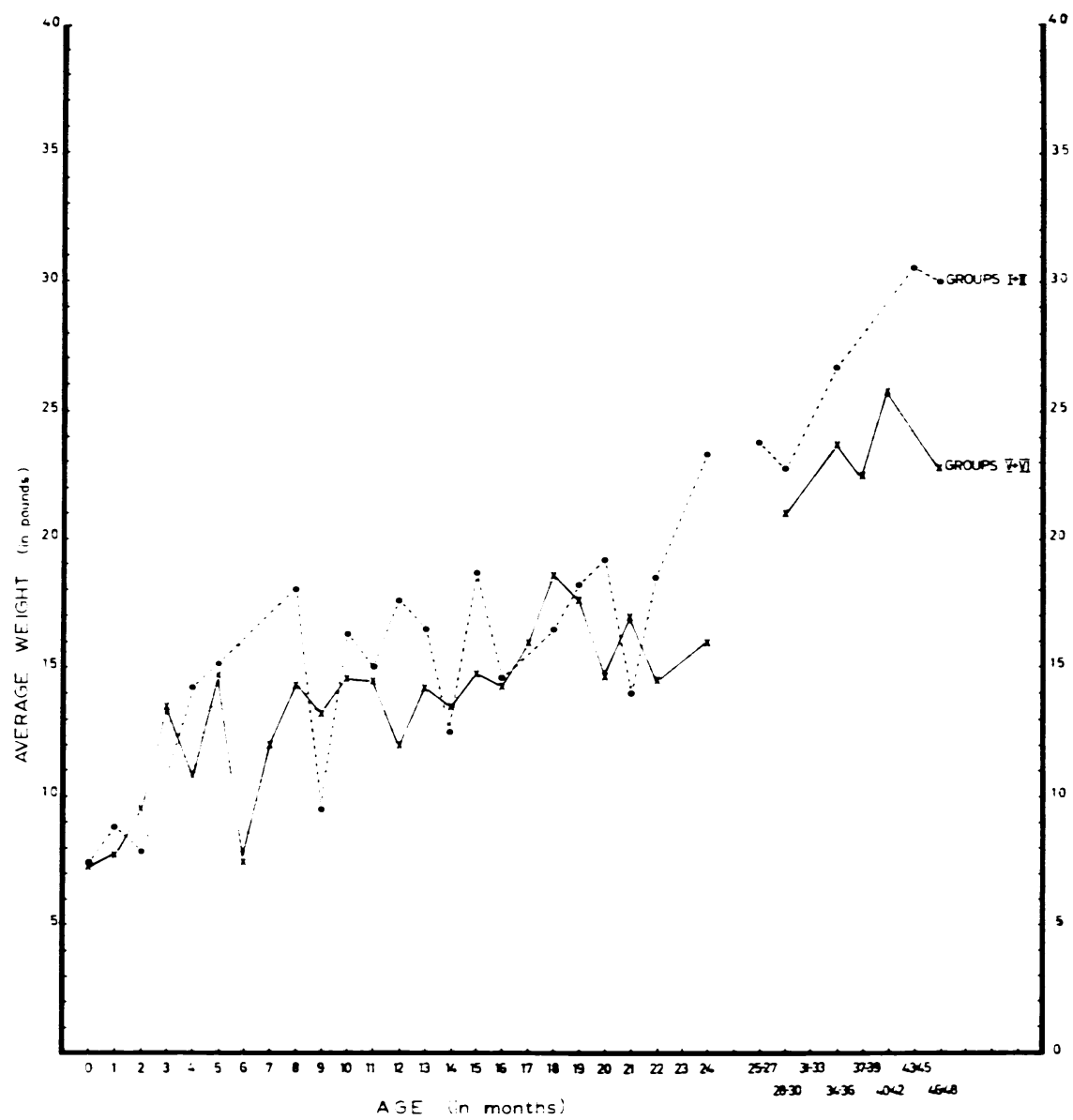

FiG. 7.-Average weights of children of fathers in socio-economs Groups I - II and V $\div$ VI.

345 died, a mortality of $26.9 \%$. By contrast, the mothers' socio-economic groups, and even more their literacy, have a marked effect on the number of children who perish. The mothers of the three highest socio-economic groups had 1,314 children and lost $19 \cdot 2 \%$, whereas mothers of Group V and VI had 1,543 children and lost $27 \cdot 1 \%$, a highly significant finding. Of the literate mothers' children, $15 \%$ died, whereas mothers who had never been to school lost $26 \%$ of their children.

This very marked and statistically significant effect of the mothers' educational attainment on the mortality (and, obviously, the morbidity) of their children seems to be exceedingly important. It is a strong pointer to the most efficient method of improving child health in the emerging countries: formal schooling of girls will, in due course, result in efficient child care.
At the time of this investigation, there was, as yet, little evidence of Family Limitation. Parents of the more educated, monogamous, higher social groups had an average of 2.5 children per mother, while the mothers in the lowest socio-economic groups, more often illiterate and frequently belonging to a polygamous household, averaged $3 \cdot 1$ children to each mother. Even so, a tendency to family planning is beginning to emerge. This is to be expected in a society of this kind, as family planning precedes wide dissemination of contraceptive techniques, as pointed out by Dubos (1959). On the other hand, in the author's opinion, no effective birth control campaign can be started in any society until and unless the preventive and curative medical services are of a sufficiently high standard to guarantee the survival of more than seven or eight out of each 10 children born. 


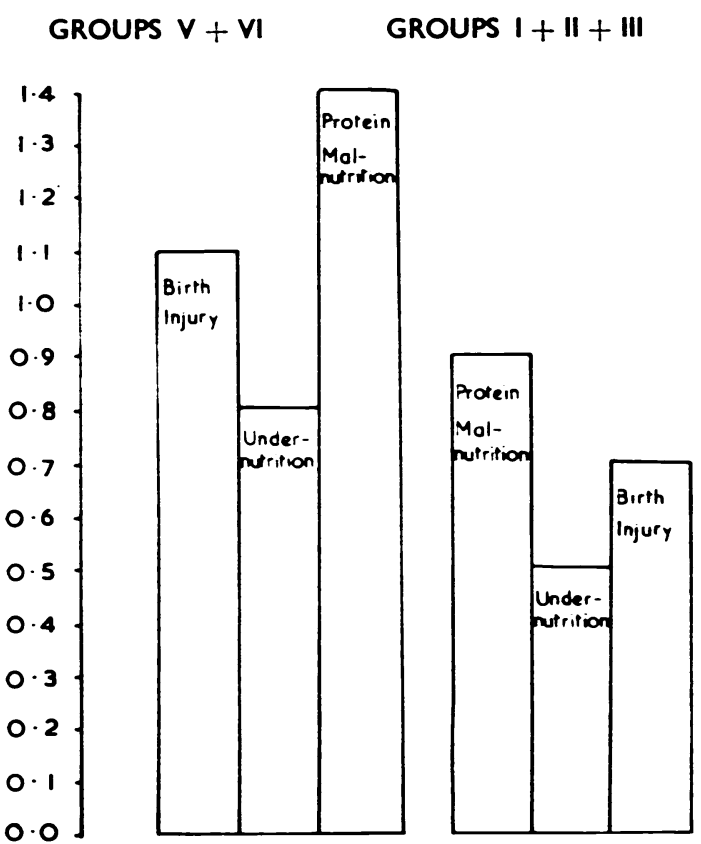

Fig. 8.-Percentage incidence of certain diseases in children whose mothers belonged to Groups V - VI and Groups I - II - III

It was thought to be of interest to determine the effect of the mothers' status on certain disease conditions in their children. The illnesses investigated were undernutrition, that is, starvation and not weight loss due to disease; protein malnutrition, here grouped together with frank kwashiorkor; and birth injuries, usually the various types of Little's disease, but also including some fractures and brachial plexus lesions.

The incidence of protein malnutrition, starvation and birth injury was not unexpectedly greater among children whose parents belonged to the two lowest socio-economic groups than among those of the top three groups (Fig. 8), though parental affluence by no means protected their children from either mal- or undernutrition. In the case of polygamous families (Fig. 9) a similar state of affairs is observed when they are compared with the offspring of monogamous marriages. The apparently disproportionately high incidence of children with undernutrition in the polygamous families may well reflect the fact that incomes and literacy rate were lower in polygamous than in monogamous families, and therefore unrelated to the fathers' marital habits. This is at variance with Marris's finding that the more wives a man had, the greater his income. It is possible that a polygamous father's
MORE THAN

ONE WIFE

ONLY ONE WIFE

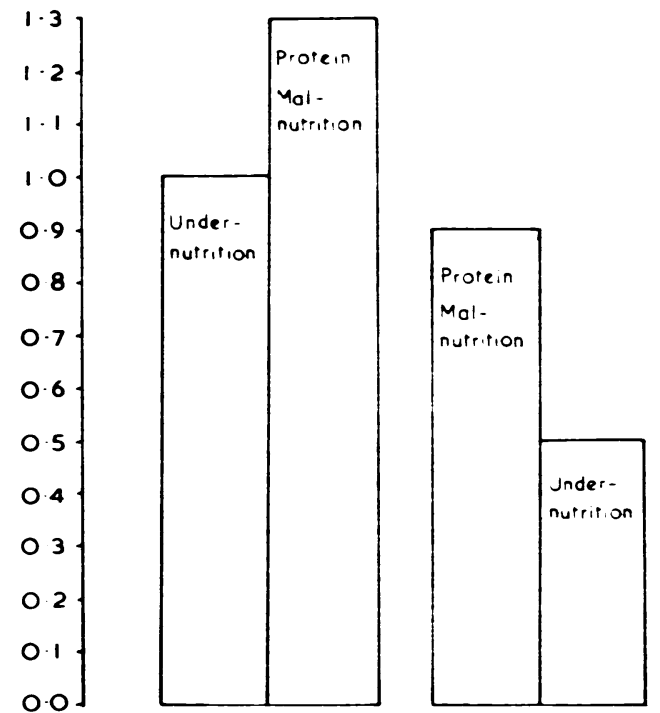

Fig. 9.-Percentage incidence of protein malnutrition and undernutrition in children of families where there was more than one wife and only one wife.

higher income did not necessarily ensure that his wives' incomes were also high. As the mother was usually responsible for the purchase of her children's food from her trade profits the child might suffer if her profit was low. The most marked difference is found (Fig. 10) in the incidence of protein malnutrition and undernutrition in children whose mothers were literate as opposed to those who were not. It seems worth stressing that protein malnutrition, in particular, was least common in children of mothers who had attended school and that the mothers' literacy appeared to have a greater effect on the children's correct nutrition than the mothers' income. As in the mortality of children of literate as compared with illiterate mothers, the vital influence of maternal schooling on the children's health is apparent. Evidently, attacking the problem of protein malnutrition and kwashiorkor through instruction of literate mothers and, equally important, schoolgirls, is well worth while. On the other hand, the finding that the incidence of birth injury among the children of literate and illiterate mothers is almost equal is noteworthy. No reason for this state of affairs can be deduced from the data available.

Fig. 11 shows the age incidence of undernutrition. The large number of cases in the youngest age- 


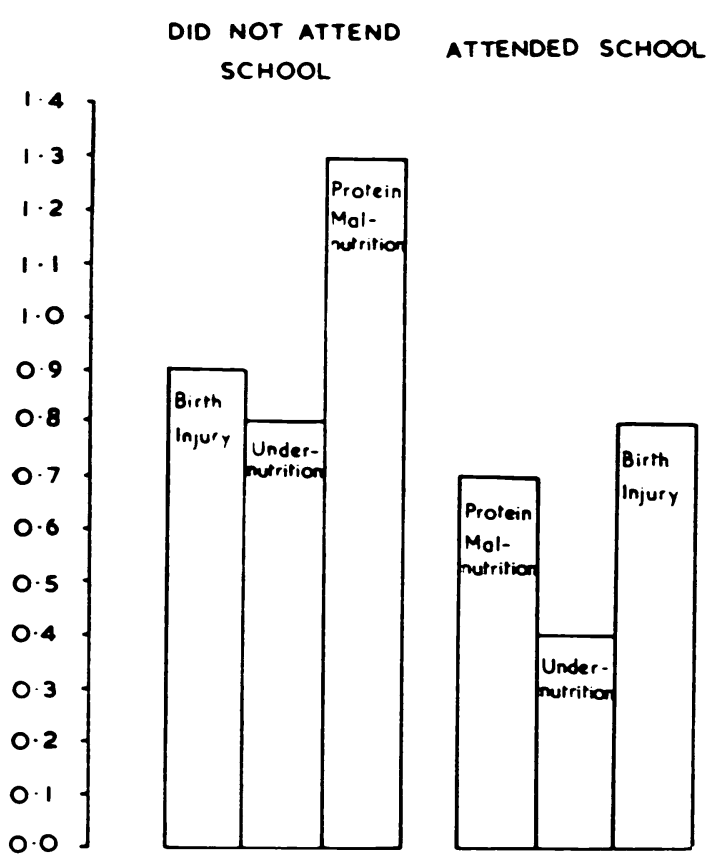

Fig. 10.-Percentage incidence of certain diseases in children whose mothers did not attend and did attend school.

groups was probably mainly due to prematurity, though maternal death or failure of lactation are other possible aetiological factors. The greater incidence of starvation in boys as compared with girls $(40: 29)$ is noteworthy. The reason for this different sex incidence must be speculative. It might be the result of the greater degree of immaturity of premature male infants, or it might reflect a greater parental concern over the health of male as compared with female children.
Fig. 12 confirms the well-known fact that protein malnutrition in its various forms reaches a peak between the ages of 18 and 30 months. The sex incidence was equal, there being 54 boys and 50 girls. The youngest child with kwashiorkor was one of 4 months, who also had a spina bifida. Among the out-patients under discussion, the oldest child with protein malnutrition was $\mathbf{4 3}$ months of age. Clearly, the upper age limit for this disease, if such a limit exists, was higher, as appeared from a review of in-patient material at the same time (Gans, 1961).

As regards information relating to the parents, we find, not unexpectedly, that mothers belonging to the first three socio-economic groups had attended school quite significantly more often than those of Groups V and VI (47.2\% as against $0.9 \%)$. A similar trend is seen among women married to men of the first two socio-economic groups, when comparing them with those married to men of Groups V and VI. In the first two Groups, 199 $(54.9 \%)$ of 362 mothers were literate in the sense of having attended school, whereas only $59(12.7 \%)$ of 459 women married to men of the lowest groups had received any schooling. Also, literacy was more common among only wives than among those married to polygamous men. Of 665 mothers in monogamous families $218(32.8 \%)$ had attended school; of 398 mothers in polygamous families, $77(19 \cdot 2 \%)$ had attended school. In this sample $70.7 \%$ of mothers in monogamous households came from the first three socio-economic groups while of the mothers of Groups V and VI, only $52.7 \%$ were the only wives.

In a later communication it is intended to report the incidence and type of illness found and their relation to the mothers' and fathers' social and cultural state; also the incidence and type of congenital abnormalities; the effect of parity, literacy and polygamy on birth injury, and the marital

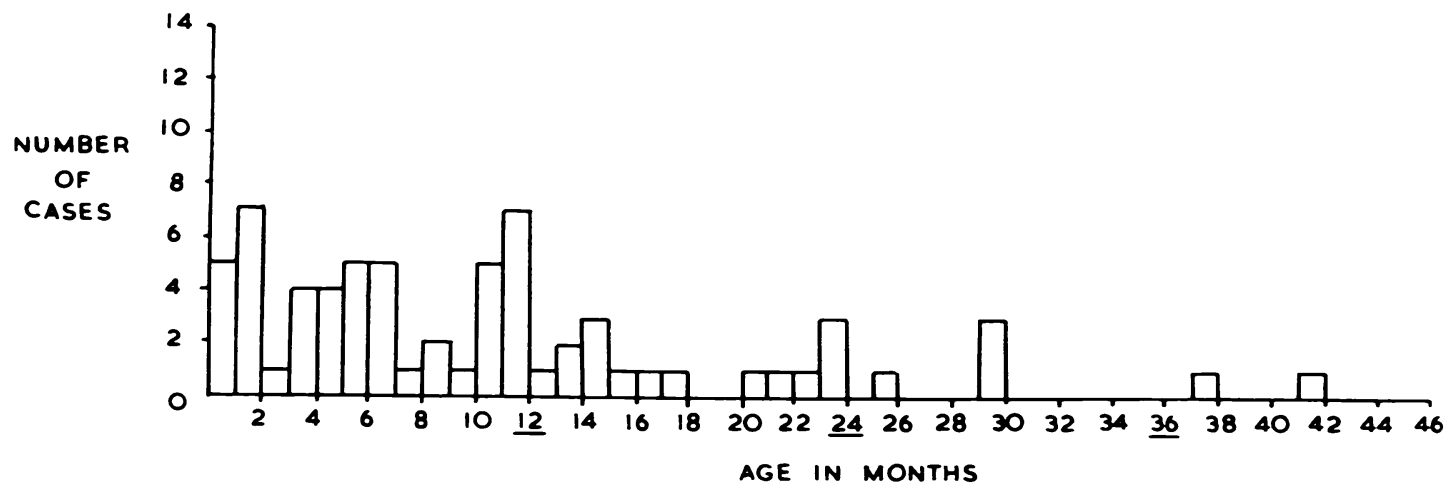

FKG. 11.-Age in months of children with undernutrition (40 boys. 29 girls). 


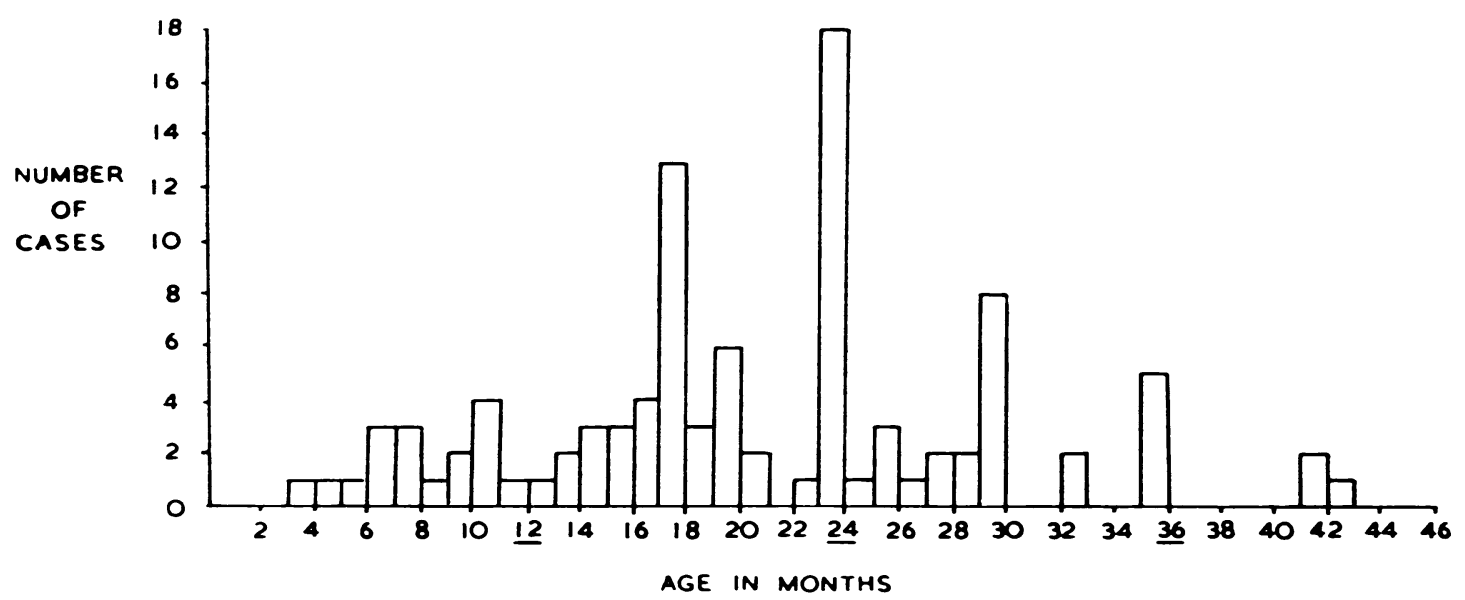

Fig. 12.-Age in months of children with protein malnutrition ( 54 boys. 50 girls).

intermixture between the various socio-economic groups.

\section{Summary}

Between 1959 and 1961, information was collected about the age, weight and sex of 984 children attending the only specialist paediatric out-patient clinic in Lagos, Nigeria. The age range was from newborn babies to 60 months. Their illnesses included a great variety of medical and surgical conditions, most of them acute. A fair proportion of children had nothing wrong with them and were brought up because of parental anxiety over their health.

Information was also sought about these children's mothers. Their socio-economic groups, their past school attendance and the number and survival of their other children were recorded. Information is available on whether these mothers came from monogamous or polygamous households. Finally, the fathers were allocated to one of six socioeconomic groups.

It was found that, apart from the neonatal period, there was a startling weight range for each of the children's age-groups. The statistical and medico-social implications of this finding are commented upon. The average weight of each agegroup was compared with the weight of children reported in other series, both in and outside Africa. Apart from the weights of newborn infants, the weights of these children were well below those reported by other investigators.

The children of literate mothers weighed more than those whose mothers had received no formal education. Similarly, children of mothers belonging to the higher socio-economic groups were heavier than those with poor mothers. On the other hand. polygamy had no effect on the children's weight.

The fathers' socio-economic group had no effect on their offsprings' weight during early childhood, though children of better-off fathers appeared to be at a slight advantage after the age of 2 years.

In polygamous households $26.9 \%$ of children born to any one mother died from some illness, whereas in monogamous households the death rate was $20.3 \%$. Mothers of the first three socioeconomic groups lost $19.2 \%$ of their offspring, as compared with $27.1 \%$ in the case of mothers of the two lowest groups. Significantly, only $15 \%$ of children of literate mothers died, while mothers without schooling lost $26 \%$.

The average family size of literate mothers was $2 \cdot 5$ children, that of illiterate mothers was $3 \cdot 1$. The feasibility of birth control is discussed.

Protein malnutrition, undernutrition and birth injury were selected for more detailed analysis. All three, though birth injury less markedly, were more common in children whose mothers belonged to the lower socio-economic groups, were illiterate, or belonged to polygamous households. The effect of past school attendance by the mothers on the mortality and morbidity of their children is stressed, particularly in relation to protein malnutrition and undernutrition.

Undernutrition was found to be most common in the lowest age-groups. Protein malnutrition reached a peak incidence at 24 months. The sex incidence of protein malnutrition was equal, that of undernutrition showed a preponderance of boys.

Mothers of the higher socio-economic groups and 
those married to men belonging to those groups, were more frequently literate than poorer mothers, or mothers married to poorer men. Literate mothers more commonly belonged to monogamous than to polygamous households. The same held for mothers of the higher socio-economic groups.

It is a pleasure to record my indebtedness to Drs. S. L. Adesuye and W. J. Martin, to Mr. P. Marris and Prof. F. Pollock, and to Mr. Osikominu and Mr. Pyte for their help and advice in preparing this paper. Also. to the Public Health Department, Lagos Town Council, and the West African Council for Medical Research for their purchase of a weighing machine, and to my House Physicians and Nurses for their help in explaining. interpreting and translating.

\section{REFERENCES}

Carter. F. S. (1961). Paediatrics in Freetown, Sierra Leone. Arch. Dis. Childh. 36, 190.

Dean, R. F. A. and Jelliffe, D. B. (1960). The diagnosis and treatment of protein-calorie malnutrition. Courrier, 10, 429.

Dubos, R. J. (1959). Mirage of Health. Allen and Unwin, London. Gubos, R. J. (1959). Mirage of Health. Allen and Unwin, London. $10,33$. Luder. J. (1957). Some paediatric problems of Uganda. Brit.

MacGregor, M. (1958). Paediatrics in Western Nigeria. Arch. Dis. Childh., 33, 277.

Marris. P. (1961). Family and Social Change in an African City. Routledge and Kegan Paul, London.

Musoke. L. K. (1961). An analysis of admissions to the paediatric division. Mulago hosjital in 1959. Arch. Dis. Childh., 36, 305. Nelson. W. E. (1959). Textbook of Pediatrics, 7th ed. Saunders. Philadelohia and London.

Population Census (1953). Department of Statistics, Lagos Government Printer.

Senecal, J.. Aubry. L. and Falade. S. (1962). Infectious diseases in the child of pre-school age in Senegal. West Afr. med. J. 11,93 .

Watt. A. (1959). Assessment of growth of Lagos babies. ibid., 8, 53. 